\title{
Saint Wilgefortis: sudden hirsutism to prevent an unwanted marriage
}

\author{
F. H. de Jong ${ }^{1}$ W. W. de Herder ${ }^{1}$
}

Received: 25 May 2016 / Accepted: 27 May 2016 / Published online: 8 June 2016

(C) Italian Society of Endocrinology (SIE) 2016

According to legend, Saint Wilgefortis, also known as Saint Ontcommer, was a beautiful Portuguese princess. Her father arranged for her to marry the pagan king of Sicily. Since she had converted to Christianity, she refused and prayed to become ugly. As a result, she suddenly grew a full beard, the Sicilian king repudiated her, and the father was enraged and had her crucified, just like her saviour. Saint Wilgefortis was venerated in Austria, Germany, Northern France and the Low Countries, especially by women who wished to be liberated from abusive husbands. Figure 1 is a reproduction of a fresco in the St. Stevenschurch in Nijmegen, The Netherlands.

The possible diagnosis might be an ovarian of adrenal testosterone-producing tumour, as also postulated for Maddalena Ventura [1]. The short time period in between her engagement and the excessive hair growth makes it unlikely that congenital adrenal hyperplasia plays a role; this diagnosis has been made in retrospect to explain the case of Pope Joan [2]. However, a completely different explanation for the appearance of the saint is found in the theory that the picture of the Volto Santo of Lucca, a crucifix representing a robed, in contrast to a loin cloth wearing Christ, was misinterpreted as representing a crucified woman, thus leading to the Wilgefortis myth.

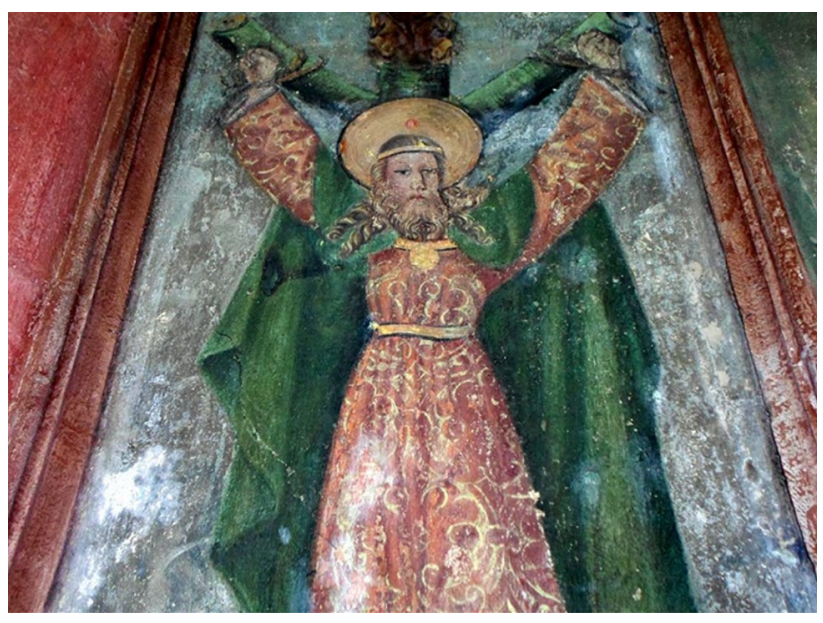

Fig. 1 Saint Wilgefortis

Compliance with ethical standards

Conflict of interest The authors declare that they have no conflict of interest.

Ethical approval This paper does not contain any studies with human participants or animals performed by any of the authors.

Informed consent No informed consent.

\section{References}

F. H. de Jong

f.h.dejong@erasmusmc.nl

1 Sector of Endocrinology, Department of Internal Medicine, Erasmus University Medical Center, Rotterdam, The Netherlands

1. Oranges CM, Matucci-Cerinic M (2016) Maddalena Ventura: an impressive case of hirsutism in a painting of Jusepe De Ribera (1631). J Endocrinol Invest 39:123

2. New ME, Kitzinger ES (1993) Pope Joan: a recognizable syndrome. J Clin Endocrinol Metab 76:3-13 